\title{
Determining Critical Success Factors for Public-Private Partnership Asset-Backed Securitization: A Structural Equation Modeling Approach
}

\author{
Li Liu $^{1}$, Yubo Guo ${ }^{2, *}$, Chuan Chen ${ }^{2}$ and Igor Martek ${ }^{3}$ \\ 1 School of Economics, Sichuan University, Chengdu 610064, China; liuli2015scu@gmail.com \\ 2 Business School, Sichuan University, Chengdu 610064, China; chuanc2012@gmail.com \\ 3 School of Architecture and Built Environment, Deakin University, Geelong, VIC 3220, Australia; \\ igormartek@yahoo.com \\ * Correspondence: guoyubo2021@gmail.com
}

Citation: Liu, L.; Guo, Y.; Chen, C.; Martek, I. Determining Critical Success Factors for Public-Private Partnership Asset-Backed Securitization: A Structural Equation Modeling Approach. Buildings 2021, 11, 199. https://doi.org/10.3390/ buildings11050199

Academic Editor: David Arditi

Received: 22 March 2021

Accepted: 5 May 2021

Published: 9 May 2021

Publisher's Note: MDPI stays neutral with regard to jurisdictional claims in published maps and institutional affiliations.

Copyright: (c) 2021 by the authors. Licensee MDPI, Basel, Switzerland. This article is an open access article distributed under the terms and conditions of the Creative Commons Attribution (CC BY) license (https:// creativecommons.org/licenses/by/ $4.0 /)$.

\begin{abstract}
Public-private partnership (PPP) has been widely applied in China and many developing countries in the recent decade. As new PPP projects gradually enter the operational phase, the issue of refinancing becomes increasingly important. PPP-ABS plays an indispensable role in PPP project refinancing. The factors that promote the success of the emerging PPP-ABS in the China financial market need to be determined. To accomplish two objectives, namely, to identify critical success factors (CSFs) and to explore the relationship between these factors and the success of the PPP asset-backed securitization (PPP-ABS) of this research, methods such as a questionnaire survey and structural equation modeling (SEM) were conducted successively. Four success factors, including underlying asset quality (UAQ), original equity holder credit (OEHC), rationality of security design (RoSD) and maturity of relative institutions (MoRI), were identified in this study. Consequently, nineteen theoretical hypotheses were developed and tested. It is shown in the SEM approach that UAQ and OEHC positively influence the success of PPP-ABS, alongside issuance characteristics (IC) that mediate the relationship between the success of PPP-ABS and UAQ, RoSD and MoRI, respectively. This finding increased knowledge of PPP-ABS and how investors and government can benefit from it.
\end{abstract}

Keywords: public-private partnership; asset-backed securitization; critical success factors; structural equation modeling

\section{Introduction}

Public-private partnerships (PPP) have been discussed by many researchers, and practitioners have defined PPP in various concepts [1]. In China, identified PPPs are generally defined as 'a long-term cooperation' between the government at all levels and social capital [2,3]. Although PPP is delivered in various forms, providing public facilities or services is the core of China's PPP. Therefore, PPP is defined in the present study as ' $\mathrm{a}$ long-term cooperation between government and social capital that aims to provide public assets or services, in which both sides share risks and benefits.' PPP has been widely applied to infrastructure development in developed and developing countries [4]. In China, a total of 9954 projects were managed with an investment of CNY 15.3 trillion by 30 November 2020 [5].

With the rapid development of PPP in China, the ways to finance and promote the implementation of projects are receiving an increasing amount of attention [6]. It is difficult for PPP projects to obtain support from financing institutions because of the large investment, low profitability and unstable cash flow [7]. The Chinese government has issued documents and policies to encourage the development of PPP asset-backed securitization (PPP-ABS). In 2016, the National Development and Reform Commission 
and China Securities Regulatory Commission jointly promoted qualified PPP projects to realize market-based financing through ABS [8]. In 2017, several departments proposed to launch PPP-ABS in certain excellent projects [9]. Afterward, with the issuing of Beijing Capital Co., Ltd., Sewage Treatment income-charging rights PPP-ABS and China Fortune Land Development Co., Ltd. and Gu'an Industrial Park Heating income-charging rights PPP-ABS, the PPP-ABS formally entered the execute phase in China. PPP-ABS is in its primary period, even if PPPs have been booming in China in the last decade. PPP-ABS in China is facing problems, such as liquidity shortage, maturity mismatch and incomplete risk isolation [10-12]. The factors that can promote success, especially for an emerging and challenging PPP-ABS market, need to be determined.

The first definition of critical success factors (CSFs) came from Rockart, who believed that CSFs refer to a few factors affecting entrepreneurs' actions to achieve goals; enterprises would suffer from a negative impact if those factors are not achieved [13]. Subsequently, numerous scholars applied the CSFs theory to various research areas $[14,15]$. CSFs can be explained as a management mechanism or an effective means for enterprises to obtain core competitiveness and reach success $[16,17]$. Scholars and practitioners know little about the CSFs of PPP-ABS, even if many studies on CSFs have focused on PPP itself. For instance, one study pointed out that one of the three most critical success factors in the U.K. PPP projects is 'available financial market' [18]. In another paper, the 'availability of finance market' is one of the top five success factors of PPP implementation in Malaysia [19]. An available financial market is essential for the successes of PPP and PPP-ABS. Although these important factors for PPP-ABS success appeared in various literatures, a gap of systematic organization of those factors still exists. Given this, the objectives of this article are to answer the following questions:

1. What are the critical success factors of PPP-ABS in China?

2. What is the relationship between these factors and the success of PPP-ABS in China?

The remainder of the paper is organized as follows. In Section 2, success attributes are identified by way of a comprehensive literature review, and research hypotheses are developed. Section 3 describes the research methodology, including questionnaire survey development, deployment and structural equation modeling (SEM) of collected data. Section 4 offers a detailed discussion of results obtained through the SEM approach. Finally, conclusions and observations on the limitations of this study are given at the end.

\section{Literature Review}

The most representative definition of ABS was from the U.S. Securities and Exchange Commission, which refers to it as a transformation process from assets lacking liquidity to securitized products that repaid principal and interest by future cash flow through a structured finance technique [20]. PPP-ABS is designed as financial security backed by the PPP infrastructure project's future receivables, such as user fees and government subsidies [21]. In China, scholars focus on two main topics, namely, PPP-ABS pricing and risks $[22,23]$. Scholars generally believe that the issuance pricing is crucial to the success of PPP-ABS because of the long-term and highly sensitive cash flow of PPP projects as the underlying asset [22]. An article pointed that the risk attributes of PPP assets are more complex compared with general financial instruments [24]. The success of PPP-ABS requires rational issuance pricing and effective risk management. The low quality of a PPP asset, unreasonable design of stock product, maturity mismatch and unclear property rights may cause the failure of PPP-ABS $[23,25,26]$.

Scholars and practitioners know much about risks and failure factors, but they know little about what factors promote the success of PPP-ABS. In a 2019 study, 25 CSFs of PPPABS were summarized as five components by the principal component analysis method, namely, effective ABS issuance and lifetime management, clear regulatory guidance, robust PPP and concessional arrangements, supportive capital market conditions and reliable underlying asset quality [21]. However, the neglect of certain special features in Chinese PPP projects was a downside. Such features included PPP initiators' identity and payment 
mechanism [5,6]. In a previous study, more than $90 \%$ of PPP projects were reported to be initiated by local governments; moreover, government payment was adopted in $34 \%$ of PPP projects [5]. The local government's fiscal situation and ability to pay are key factors that cannot be ignored in China. The capital recovery of PPP-ABS products will be affected negatively if the local government is not in the best fiscal situation [27]. Inappropriate subsidy commitment beyond local fiscal strength increases the risk of capital chain rupture in PPP-ABS $[28,29]$.

Moreover, many studies have focused on CSFs in PPP [18,30,31]. Those factors play an important role in PPP implementation and are also acting on PPP-ABS in some way. For instance, a complete legal framework and mature accounting and tax standards comprise the crucial exterior environment for a PPP infrastructure project and a PPP-ABS program [32-34]. Reasonable risk allocation and proper PPP contracts arrangement are also critical to the issuance of PPP-ABS [35,36]. Qualified underlying asset is a prerequisite for the success of ABS, and PPP-ABS is no exception $[37,38]$. However, the same factors are of different importance to PPP and PPP-ABS. Therefore, the relationship between those CSFs and success in PPP-ABS is a research gap. Various CSFs in PPP and relevant research area were ranked by various scholars $[39,40]$. Previous studies were similar in identifying those factors in the first place. The initial success attributes list of PPP-ABS from the literature is presented in Table 1.

Table 1. Initial success attributes list of PPP-ABS (Source: Authors' compilation).

\begin{tabular}{|c|c|c|}
\hline Number & Success Attributes & Sources \\
\hline SA1 & Reasonable capital structure & {$[41,42]$} \\
\hline SA2 & Effective government-payment mechanism & {$[43,44]$} \\
\hline SA3 & Accurate pricing and reasonable price adjustment & {$[45,46]$} \\
\hline SA4 & $\begin{array}{l}\text { Reasonable risk allocation and clear } \\
\text { responsibilities in PPP arrangement }\end{array}$ & {$[31,35,36]$} \\
\hline SA5 & Proper concession period & [46-48] \\
\hline SA6 & Legality of the PPP project & {$[31]$} \\
\hline SA7 & Well-designed return mechanism & [49] \\
\hline SA8 & Satisfactory ROI (return on investment) & [50-52] \\
\hline SA9 & Proper cash flow coverage ratio & {$[10,53]$} \\
\hline SA10 & Project company in favorable operation & {$[54,55]$} \\
\hline SA11 & Local government with sound fiscal situation & {$[27,29,36]$} \\
\hline SA12 & Local government with capability of paying debt & {$[28]$} \\
\hline SA13 & Local government credibility & {$[56,57]$} \\
\hline SA14 & Ownership attribute & [58-60] \\
\hline SA15 & Private sector with good reputation & {$[61,62]$} \\
\hline SA16 & Private sector with operating capability & {$[38]$} \\
\hline SA17 & Private sector with financial capability & {$[54,55,63]$} \\
\hline SA18 & Reasonable design of asset pool & {$[10,64,65]$} \\
\hline SA19 & $\begin{array}{l}\text { Reasonable cash flow gathering and payment } \\
\text { mechanism }\end{array}$ & {$[66-68]$} \\
\hline SA20 & Reasonable redemption and put-back provision & {$[69,70]$} \\
\hline SA21 & Well-designed credit trigger mechanism & {$[71]$} \\
\hline SA22 & Objective and accurate credit rating & {$[53,72]$} \\
\hline SA23 & Internal credit enhancement measures & {$[33]$} \\
\hline SA24 & External credit enhancement measures & {$[33,73]$} \\
\hline SA25 & Transparent information disclosure & {$[18,74]$} \\
\hline SA26 & Mature accounting and tax standards & {$[21,33,75,76]$} \\
\hline SA27 & Mature secondary market & [67] \\
\hline SA28 & Clear and effective governmental regulation & {$[31,34,77]$} \\
\hline
\end{tabular}

The various success attributes can be consolidated as four success factors [21]. The four success attribute groupings, numbering from SA1 to SA13, from SA14 to SA17, from SA18 to SA24 and from SA25 to SA28, can be described as underlying asset quality (UAQ), original equity holder credit (OEHC), rationality of security design (RoSD) and maturity of 
relative institutions (MoRI), respectively. The continued success of securitization depends on the efficiency of resource usage and ensuing competitiveness. That is, underlying asset quality (UAQ) has a positive influence on the success of PPP-ABS programs $[70,78]$. Given the conflict of interests that may arise among investors, trustees and other entities within ABS, stakeholders ought to take practical steps in order to maximize asset recovery and value [79]. This may be why original equity holder credit (OEHC) impacts the success of ABS since ABS depends, at least partly, on recovered asset value [80,81]. Additionally, investors should pay attention to the security structure, as a rational security design can help improve credit standing [64,71,81]. At the macro level, the asset securitization market in China is policy driven and regulation-segmented [82]. Consequently, the maturity of relative institutions affects the success of PPP-ABS significantly. To sum up, some hypotheses are developed, as follows:

Hypothesis 1 (H1). The underlying asset quality (UAQ) has a positive influence on the success of $P P P-A B S$.

Hypothesis 2 (H2). The original equity holder credit (OEHC) has a positive influence on the success of $P P P-A B S$.

Hypothesis 3 (H3). The Rationality of security design (RoSD) has a positive influence on the success of $P P P-A B S$.

Hypothesis 4 (H4). The maturity of relative institutions (MoRI) has a positive influence on the success of $P P P-A B S$.

\section{Materials and Methods}

The overall research method consists of a total of four steps as follows.

\subsection{Step 1: Identifying Success Attributes and Factors}

Desk research is an important step in almost all studies, especially in CSF studies $[17,83]$. The collection of secondary data helps elucidate foregone knowledge. Simultaneously, results of desk research can serve as a basis for further research. To identify the initial success attributes list, a review of the existing literature about PPP and/or ABS was conducted. In addition, public data of PPP-ABS programs and other relevant information from the internet were also within the scope of the desk research. Firstly, literatures about PPP-ABS were retrieved and collected. Such literatures were searched by using the Web of Science, Google Scholar and China National Knowledge Infrastructure (CNKI). These academic search engines were selected for this study based on three reasons: (1) Web of Science is the world's largest comprehensive academic information resource covering the most subjects, (2) CNKI is the most comprehensive Chinese academic resource platform, and (3) Google Scholar is the largest cross-platform academic search engine that can serve as an effective supplement to the other two platforms. Then, the following keywords were applied to the search: public-private partnerships (PPP), built-operate-transfer (BOT), built-transfer (BT), transfer-operate-transfer (TOT) and asset-backed securitization (ABS) or securitization and other translated Chinese words. Thousands of literatures were retrieved. Further filtered criteria adopted in this step include relevance to the research topic, quality of documentation and language category (English or Chinese). Finally, the literature review began, and new articles were continuously added according to the references of existing papers. An initial list including 29 PPP-ABS success attributes and 4 success factors was obtained. In addition, the list of these attributes was discussed in detail with nine experts, who had more than 5 years of experience in the PPP and/or ABS area. They came from the original equity holder, project company, consultation corporation and credit rating agency, respectively. They checked the appropriateness of these attributes to ensure that no significant success attributes were omitted. After discussing, attributes, including sufficient and stable potential demand, private sector with capability of technical progress 
and private sector protection clause were added into the final list, designated as SA29, SA30 and SA31, respectively. Based on the literature and solicited expert opinion, the many identifiable success attributes can be distilled into serval success factors $[21,64,70]$. The relationship between success factors and attributes was confirmed by factor analysis, as carried out in the following subsection. Identified success factors and attributes are shown in Table 2.

Table 2. Success factors and attributes (Source: Experts' opinions).

\begin{tabular}{|c|c|c|c|}
\hline Number & & Success Factors & Success Attributes \\
\hline SA1 & \multirow{16}{*}{$\mathrm{UAQ}^{1}$} & \multirow{9}{*}{$\begin{array}{l}\text { Rationality of PPP implementation } \\
\text { plan (UAQ1) }\end{array}$} & Reasonable capital structure \\
\hline SA2 & & & Effective government-payment mechanism \\
\hline SA3 & & & Accurate pricing and reasonable price adjustment \\
\hline SA4 & & & Reasonable risk allocation and clear responsibilities in \\
\hline & & & PPP arrangement \\
\hline SA5 & & & Proper concession period \\
\hline SA6 & & & Legality of the PPP project \\
\hline SA7 & & & Well-designed return mechanism \\
\hline SA31 & & & Private sector protection clause \\
\hline SA8 & & \multirow{4}{*}{ Stability of cash flow (UAQ2) } & Satisfactory ROI (return on investment) \\
\hline SA9 & & & Proper cash flow coverage ratio \\
\hline SA29 & & & Sufficient and stable potential demand \\
\hline SA10 & & & Project company in favorable operation \\
\hline SA11 & & \multirow{3}{*}{$\begin{array}{l}\text { Capability of local government } \\
\text { (UAQ3) }\end{array}$} & Local government with sound fiscal situation \\
\hline SA12 & & & Local government with capability of paying debt \\
\hline SA13 & & & Local government credibility \\
\hline SA14 & & \multirow{5}{*}{$\mathrm{OEHC}^{2}$} & Ownership attribute \\
\hline SA15 & & & Private sector with good reputation \\
\hline SA16 & & & Private sector with operating capability \\
\hline SA17 & & & Private sector with financial capability \\
\hline SA30 & & & Private sector with capability of technical progress \\
\hline SA18 & \multirow{7}{*}{$\operatorname{RoSD}^{3}$} & \multirow{4}{*}{ Rationality of deal structure (RoSD1) } & Reasonable design of asset pool \\
\hline SA19 & & & Reasonable cash flow gathering and payment mechanism \\
\hline SA20 & & & Reasonable redemption and put-back provision \\
\hline SA21 & & & Well-designed credit trigger mechanism \\
\hline SA22 & & \multirow{3}{*}{$\begin{array}{l}\text { Effectiveness of credit rating and } \\
\text { enhancement measures (RoSD2) }\end{array}$} & Objective and accurate credit rating \\
\hline SA23 & & & Internal credit enhancement measures \\
\hline SA24 & & & External credit enhancement measures \\
\hline SA25 & & \multirow{4}{*}{ MoRI $^{4}$} & Transparent information disclosure \\
\hline SA26 & & & Mature accounting and tax standards \\
\hline SA27 & & & Mature secondary market \\
\hline SA28 & & & Clear and effective governmental regulation \\
\hline
\end{tabular}

${ }^{1} \mathrm{UAQ}=$ underlying asset quality ${ }^{2} \mathrm{OEHC}=$ original equity holder credit; ${ }^{3} \mathrm{RoSD}=$ rationality of security design; ${ }^{4} \mathrm{MoRI}=\mathrm{Maturity}$ of relative institutions.

Defining the success of a project is not easy, as various scholars understand it differently. Generally, project success means reaching the expected goal and matching interests of differing stakeholders [84-86]. Five performance factors (profitability, satisfaction of key stakeholders, predictability of cost and time outcomes, environment, health and safety, and quality consciousness) were used to describe the success of the construction organization [87]. This is worth noting but not necessarily emulating since it is more applicable to firms rather than to PPP-ABS projects. Due to the fact that PPP-ABS starts late in China, the measure of PPP-ABS success has not formed a unified understanding. PPP-ABS projects have a dual character in that they are not only project-based but also securities-based. From the perspective of project character, the financing cost and financing scale should be considered when determining the success of PPP-ABS projects. Moreover, considering the character of $\mathrm{ABS}$, avoiding maturity mismatch and controlling financing risk are vital 
for success. Referring to the success definition of a project, PPP-ABS success is defined as the PPP-ABS products' ability to accomplish issuance in full and principal and interest payment, successfully conforming to the expected goal of the original equity holders. Four attributes were adopted to measure the success of the PPP-ABS project, as follows.

1. Reasonable financing cost (RFS): Financing cost refers to the real cost incurred in the financing process, which can be recorded in the statements generally. The financing cost of PPP-ABS includes income paid to market investors, underwriting fee, asset rating fee, etc. Exorbitant cost is not conducive to the sustainability of capital replenishment. Thus, reasonable financial cost was regarded as an attribute of PPP-ABS success.

2. Suitable financing scale (SFS): Suitable financing scale means that it is matching between actual scale of financing and expected financing scale (i.e., the issuance scale of PPP-ABS). If the financing scale exceeds the actual need, it will lead to idle capital and increase the debt burden. Otherwise, financing plans may fail if funding is less than that required [88]. In practice, raising enough funds was the precondition for the establishment of a PPP-ABS product. Therefore, a suitable financing scale was also used to measure the PPP-ABS success.

3. Suitable financing maturity (SFM): According to the basic principle of financing, the investment demand of long-term assets should be generally satisfied by longterm financing funds. The mismatch of investment and financing term will increase liquidity risk, reduce the efficiency of capital usage. In this paper, suitable financing maturity between the issuing of the PPP-ABS product and the investment of raised funds was one of the PPP-ABS success criteria.

4. Controllable financing risk (CFR): Compared with general ABS, PPP-ABS products are more complex because of the numerous stakeholders, high technical content and specific risks. Financing risks in accurately identifying, measuring and controlling play a positive role in repaying the principal and interest smoothly in the whole duration of the $\mathrm{PPP}-\mathrm{ABS}$ product. Controllable financing risk thus was adopted to measure PPP-ABS success.

All experts were satisfied with the attributes measuring the success of PPP-ABS. Moreover, the experts pointed out that features of PPP-ABS product issuance, such as issuing rate of interest and repaying date of interest, are important for market investors. They believed that success factors may influence the success of PPP-ABS products through the issuance characteristics. The issuance characteristics were likely a mediating variable, alongside their measurement structure, illustrated in Table 3.

Table 3. Mediating factors and attributes (Source: Experts' opinions).

\begin{tabular}{|c|c|c|c|}
\hline Number & & Factors & Attributes \\
\hline $\begin{array}{l}\text { IC11 } \\
\text { IC12 } \\
\text { IC13 } \\
\text { IC14 } \\
\text { IC15 }\end{array}$ & $\mathrm{IC}^{1}$ & $\begin{array}{l}\text { Rationality of issuance } \\
\text { elements (IC1) }\end{array}$ & $\begin{array}{l}\text { Issuing rate of interest } \\
\text { Issuing scale } \\
\text { Issuing duration } \\
\text { Issuing way (shelf offering or not) } \\
\text { Issuing channel }\end{array}$ \\
\hline $\begin{array}{l}\text { IC21 } \\
\text { IC22 }\end{array}$ & & $\begin{array}{l}\text { Rationality of repaying } \\
\text { characteristics (IC2) }\end{array}$ & $\begin{array}{l}\text { Repaying way of interest } \\
\text { Repaying date of interest }\end{array}$ \\
\hline
\end{tabular}

${ }^{1} \mathrm{IC}=$ issuance characteristics.

\subsection{Step 2: Collecting Data by Questionnaire Survey}

The questionnaire survey is an effective approach for understanding the structured perspectives on some professional questions [89-91]. Based on the final CSF list of PPPABS, a questionnaire survey was designed to collect the professional opinion of PPP-ABS practitioners. A 5-point Likert scale was applied to the questionnaire, as follows: (1) the point was not important, (2) was less important, (3) was neutral, (4) was important and (5) was very important. Respondents were invited to mark 1-5 points for the 31 factors. More accurate and clear descriptions were adjusted in the final questionnaire according 
to a pilot questionnaire survey that included the input of 10 experienced practitioners. In addition, the respondents' selection criteria included the following: (1) respondents should have rich experience in the field of PPP or ABS in China; (2) respondents should have a bachelor's degree in the relevant field at least; and (3) having respondents with relevant experience of PPP-ABS issuance is even better. Questionnaires were assigned to respondents by the software 'Wenjuanxing', which is a free questionnaire collection tool in China. A total of 419 respondents submitted their replies. However, 23 responses were deleted because of their duplicate filling, incomplete filling or insufficient filling time. The other 396 respondents were described statistically, as shown in Table 4. Only 47 respondents participated in the PPP-ABS issuance in their careers because of the short development of the PPP-ABS market in China, which only started to develop substantially starting from 2017. Therefore, practitioners with rich experience in PPP or ABS also became target respondents.

Table 4. Respondents' information (Source: Questionnaire).

\begin{tabular}{cccc}
\hline Respondents' & Attribute Value & Frequency & Percent \\
\hline \multirow{2}{*}{ Gender } & Male & 271 & 68.43 \\
& Female & 125 & 31.57 \\
\hline \multirow{2}{*}{ Work experience } & $\leq 3$ years & 14 & 3.54 \\
& $3-5$ years & 67 & 16.92 \\
& $5-10$ years & 112 & 28.28 \\
& $>10$ years & 203 & 51.26 \\
\hline \multirow{2}{*}{ Organization categories } & Government & 24 & 6.06 \\
& Brokers / investment banks & 167 & 42.17 \\
& Lending banks & 78 & 19.70 \\
& Trust company & 42 & 10.61 \\
& Other financial institutions & 32 & 8.08 \\
& PPP investors/private & 21 & 5.30 \\
& sectors & 12 & 3.03 \\
& Other & 20 & 5.05 \\
\hline \multirow{2}{*}{ PPP-ABS issuance experience } & PPP stakeholders & 47 & 11.87 \\
& Consultants & 349 & 88.13 \\
\hline
\end{tabular}

After collecting the questionnaires, reliability analysis and factor analysis were conducted to analyze the reliability and validity of each measurement model. As shown in Table 5, the Cronbach's alpha value for factors UAQ, OEHC, RoSD, MoRI, IC and the success of PPP-ABS were 0.970, 0.882, 0.920, 0.883, 0.933 and 0.832, respectively. Because all Cronbach's alpha values for all the factors were greater than 0.5 , the attributes grouped under the individual factors were considered reliable for further analysis [92]. In addition, extracted components by Principal Component Analysis (PCA) fit the proposed factor structure in Tables 2 and 3. 
Table 5. Reliability analysis and factor analysis (Source: Authors' calculations).

\begin{tabular}{|c|c|c|c|c|c|c|c|c|}
\hline \multirow{2}{*}{\multicolumn{2}{|c|}{ Factors }} & \multirow{2}{*}{ Attributes } & \multicolumn{2}{|c|}{ Descriptive Statistics } & \multicolumn{3}{|c|}{ Component } & \multirow{2}{*}{ Cronbach's Alpha } \\
\hline & & & Mean & Std. & 1 & 2 & 3 & \\
\hline \multirow{15}{*}{ UAQ } & \multirow{8}{*}{ UAQ1 } & SA1 & 3.86 & 1.012 & 0.779 & 0.300 & 0.299 & \multirow{15}{*}{0.970} \\
\hline & & SA2 & 3.96 & 0.984 & 0.761 & 0.372 & 0.254 & \\
\hline & & SA3 & 3.88 & 0.996 & 0.751 & 0.343 & 0.363 & \\
\hline & & SA4 & 3.88 & 1.003 & 0.714 & 0.282 & 0.350 & \\
\hline & & SA5 & 3.90 & 0.994 & 0.625 & 0.391 & 0.385 & \\
\hline & & SA6 & 3.93 & 0.965 & 0.608 & 0.334 & 0.288 & \\
\hline & & SA7 & 3.87 & 1.012 & 0.571 & 0.343 & 0.313 & \\
\hline & & SA31 & 4.10 & 0.986 & 0.561 & 0.399 & 0.339 & \\
\hline & \multirow{4}{*}{ UAQ2 } & SA8 & 4.03 & 1.026 & 0.298 & 0.781 & 0.291 & \\
\hline & & SA9 & 4.04 & 1.028 & 0.398 & 0.754 & 0.262 & \\
\hline & & SA29 & 4.27 & 1.032 & 0.218 & 0.658 & 0.301 & \\
\hline & & SA10 & 4.00 & 0.976 & 0.390 & 0.504 & 0.237 & \\
\hline & \multirow{3}{*}{ UAQ3 } & SA11 & 3.90 & 1.039 & 0.334 & 0.237 & 0.825 & \\
\hline & & SA12 & 3.80 & 0.986 & 0.372 & 0.304 & 0.639 & \\
\hline & & SA13 & 3.92 & 0.990 & 0.374 & 0.343 & 0.592 & \\
\hline \multirow{5}{*}{\multicolumn{2}{|c|}{ OEHC }} & SA14 & 4.08 & 1.053 & 0.893 & - & - & \multirow{5}{*}{0.882} \\
\hline & & SA15 & 3.94 & 1.048 & 0.882 & - & - & \\
\hline & & SA16 & 3.85 & 1.043 & 0.848 & - & - & \\
\hline & & SA17 & 3.51 & 1.243 & 0.831 & - & - & \\
\hline & & SA30 & 3.95 & 1.014 & 0.696 & - & - & \\
\hline \multirow{7}{*}{\multicolumn{2}{|c|}{ RoSD2 }} & SA18 & 3.47 & 1.041 & 0.873 & 0.187 & - & \multirow{7}{*}{0.920} \\
\hline & & SA19 & 3.58 & 1.058 & 0.750 & 0.366 & - & \\
\hline & & SA20 & 3.57 & 1.084 & 0.742 & 0.391 & - & \\
\hline & & SA21 & 3.53 & 1.054 & 0.693 & 0.385 & - & \\
\hline & & SA22 & 3.43 & 1.046 & 0.213 & 0.847 & - & \\
\hline & & SA23 & 3.73 & 0.996 & 0.442 & 0.740 & - & \\
\hline & & SA24 & 3.80 & 0.996 & 0.433 & 0.671 & - & \\
\hline \multirow{4}{*}{\multicolumn{2}{|c|}{ MoRI }} & SA25 & 3.86 & 1.050 & 0.882 & - & - & \multirow{4}{*}{0.883} \\
\hline & & SA26 & 4.08 & 1.183 & 0.874 & - & - & \\
\hline & & SA27 & 3.95 & 1.094 & 0.856 & - & - & \\
\hline & & SA28 & 4.09 & 1.135 & 0.833 & - & - & \\
\hline \multirow{7}{*}{ IC } & \multirow{7}{*}{ IC2 } & IC11 & 3.85 & 1.063 & 0.879 & 0.304 & - & \multirow{7}{*}{0.933} \\
\hline & & IC12 & 3.92 & 1.027 & 0.863 & 0.323 & - & \\
\hline & & IC13 & 3.74 & 0.982 & 0.804 & 0.380 & - & \\
\hline & & IC14 & 3.88 & 1.013 & 0.763 & 0.386 & - & \\
\hline & & IC15 & 3.94 & 0.991 & 0.693 & 0.408 & - & \\
\hline & & IC21 & 3.65 & 0.956 & 0.279 & 0.891 & - & \\
\hline & & IC22 & 3.54 & 1.044 & 0.318 & 0.661 & - & \\
\hline \multirow{4}{*}{\multicolumn{2}{|c|}{ Success of PPP-ABS }} & RFS & 3.62 & 0.945 & 0.850 & - & - & \multirow{4}{*}{0.832} \\
\hline & & SFS & 3.79 & 0.911 & 0.818 & - & - & \\
\hline & & SFM & 3.54 & 0.945 & 0.814 & - & - & \\
\hline & & CFR & 3.78 & 1.047 & 0.780 & - & - & \\
\hline
\end{tabular}

\subsection{Step 3: Developing Theoretical Hypotheses}

In summary, a theoretical framework was established to draft the relationship between success factors and the success of PPP-ABS, as shown in Figure 1. 


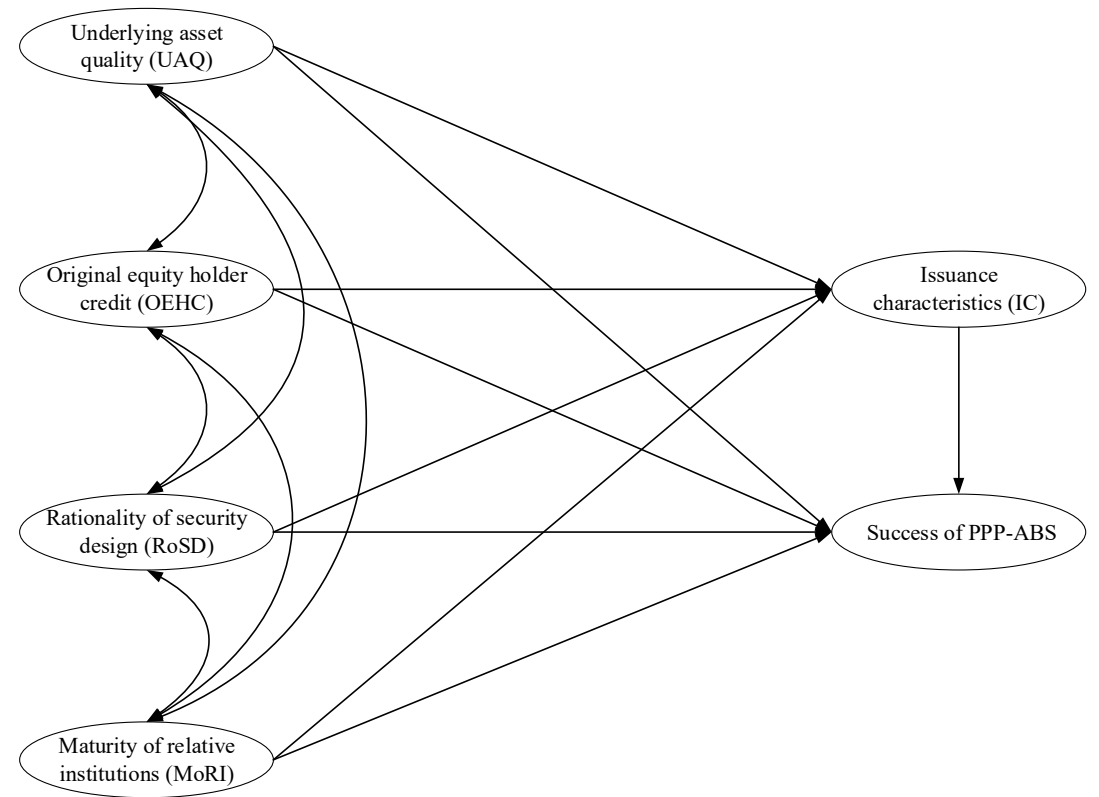

Figure 1. Research steps of this study.

According to the proposed framework model, additional hypotheses regarding the relationship between success factors and the success of PPP-ABS were tested as follows:

Hypothesis $\mathbf{5}$ (H5). The underlying asset quality (UAQ) has a positive influence on issuance characteristics (IC).

Hypothesis 6 (H6). The original equity holder credit (OEHC) has a positive influence on issuance characteristics (IC).

Hypothesis 7 (H7). The rationality of security design (RoSD) has a positive influence on issuance characteristics (IC).

Hypothesis 8 (H8). The maturity of relative institutions (MoRI) has a positive influence on issuance characteristics (IC).

Hypothesis 9 (H9). The issuance characteristics (IC) has a positive influence on the success of $P P P-A B S$.

Hypothesis 10 (H10). There is a significant correlation between the underlying asset quality (UAQ) and the original equity holder credit (OEHC).

Hypothesis 11 (H11). There is a significant correlation between the underlying asset quality (UAQ) and the rationality of security design (RoSD).

Hypothesis 12 (H12). There is a significant correlation between the underlying asset quality $(U A Q)$ and the maturity of relative institutions (MoRI).

Hypothesis 13 (H13). There is a significant correlation between the original equity holder credit (OEHC) and the rationality of security design (RoSD).

Hypothesis 14 (H14). There is a significant correlation between the original equity holder credit (OEHC) and the maturity of relative institutions (MoRI).

Hypothesis 15 (H15). There is a significant correlation between the rationality of security design (RoSD) and the maturity of relative institutions (MoRI). 
Hypothesis 16 (H16). The issuance characteristics (IC) partially mediates the relationship between the underlying asset quality $(U A Q)$ and the success of $P P P-A B S$.

Hypothesis 17 (H17). The issuance characteristics (IC) partially mediates the relationship between the original equity holder credit (OEHC) and the success of PPP-ABS.

Hypothesis 18 (H18). The issuance characteristics (IC) partially mediates the relationship between the rationality of security design (RoSD) and the success of $P P P-A B S$.

Hypothesis 19 (H19). The issuance characteristics (IC) partially mediates the relationship between the maturity of relative institutions (MoRI) and the success of PPP-ABS.

\subsection{Step 4: Validating Hypotheses Model}

The hypothesized model was analyzed using AMOS 22 software, which is used for SEM. The maximum likelihood method of estimation was used in this study. The adequacy of the model is evaluated from the results of the covariance structural analysis, which is indicated by the goodness of fit measures, shown in Table 6. Measuring the goodness-of-fit is an important part in developing structural equation models and a large number of goodness-of-fit criteria have been developed for this purpose. Generally, three types of model-fit measures are used to judge the fitness of the measurement components: absolute fit, incremental fit and parsimonious fit [93]. Of these, in this phase, giving $\chi^{2}=1686.251$ $\left(\mathrm{df}=797, \chi^{2} / \mathrm{df}=2.116\right)($ Table 6$)$. As the $\chi^{2} / \mathrm{df}$ value is lower than 5 , this indicates an acceptable fit [94]. The final SEM model is shown in Figure 2.

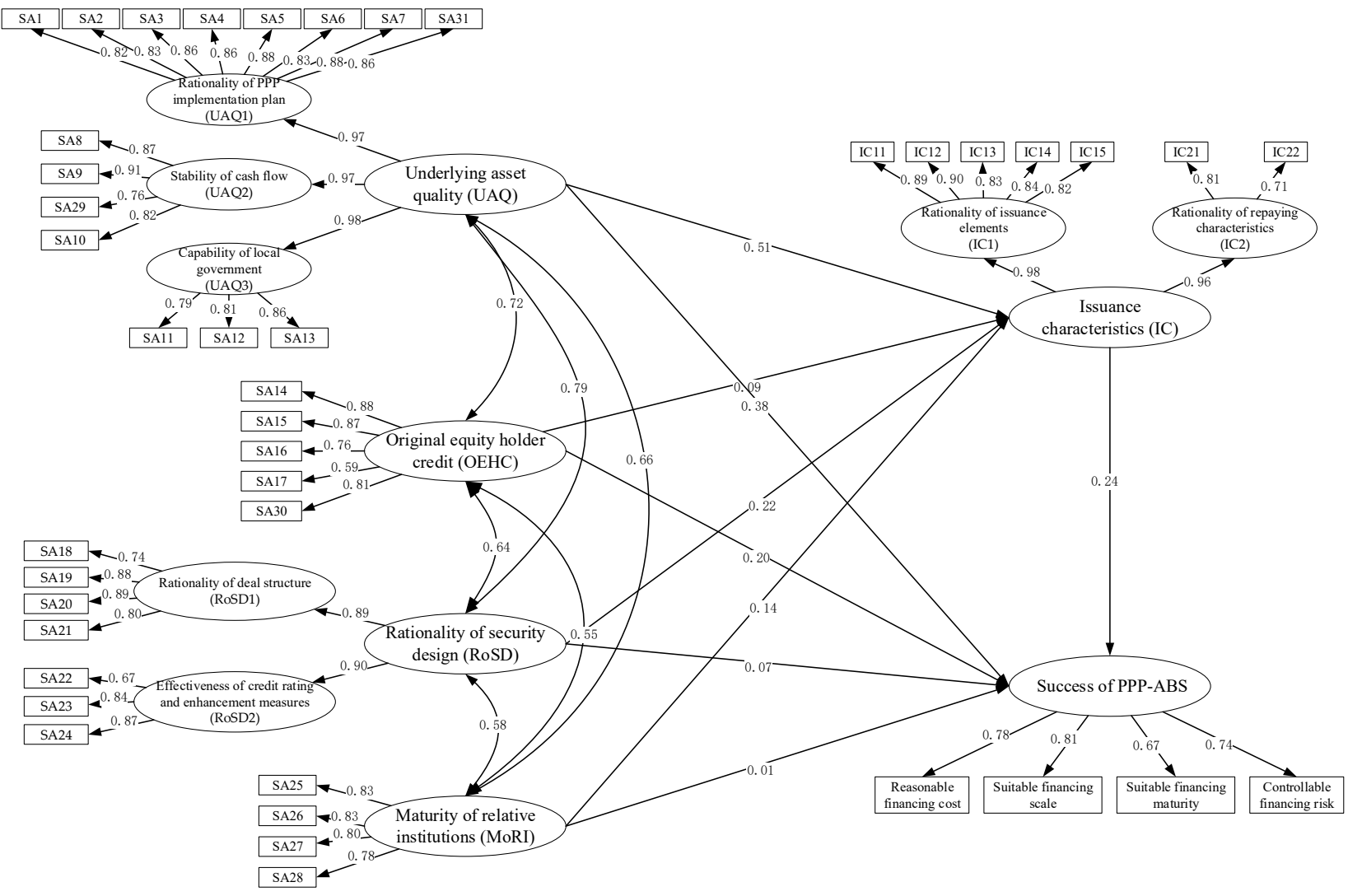

Figure 2. Final SEM model (relative contribution of CSFs on the constructs alongside path coefficients). 
Table 6. Goodness-of-fit measures results (Source: Authors' calculations).

\begin{tabular}{cccc}
\hline \multicolumn{2}{c}{ Goodness-of-Fit Measures } & Index & Criteria $^{\mathbf{1}}$ \\
\hline \multirow{2}{*}{ Absolute fit } & $\chi^{2} / \mathrm{df}$ & 2.116 & $<5$ \\
& SRMR & 0.0408 & $<0.05$ \\
& RMSEA & 0.047 & $<0.08$ \\
\hline \multirow{2}{*}{ Incremental fit } & CFI & 0.922 & $>0.9$ \\
& TLI & 0.915 & $>0.9$ \\
& IFI & 0.922 & $>0.9$ \\
\hline \multirow{2}{*}{ Parsimonious fit } & RFI & 0.901 & $>0.9$ \\
& PNFI & 0.798 & $>0.5$ \\
\hline
\end{tabular}

${ }^{1}$ Adapted from [93].

\section{Results and Discussions}

\subsection{Path Analysis among Latent Variables}

As shown in Table 7, the main research finding is that UAQ and OEHC positively influence (have a positive influence on) the success of PPP-ABS. Additionally, H10, H11, H12, H13, H14 and H15 hypotheses are supported, which means that there are significant correlations between UAQ, OEHC, RoSD and MoRI. In addition, the hypotheses other than H6, H5, H7, H8 and H9 hypotheses are supported, i.e., UAQ, RoSD and MoRI have a positive influence on issuance characteristics (IC), and IC positively influence the success of PPP-ABS.

Table 7. Results of path analysis (Source: Authors' calculations).

\begin{tabular}{lcccccc}
\hline \multicolumn{2}{c}{ Hypothesized Relationships } & Path Coefficient & S.E. & C.R. & Sig. & Interpretation \\
\hline H1 & Success of PPP-ABS $\leftarrow$ UAQ & 0.381 & 0.143 & 2.39 & $0.017^{1}$ & Supported \\
H2 & Success of PPP-ABS $\leftarrow$ OEHC & 0.204 & 0.074 & 2.438 & $0.015^{1}$ & Supported \\
H3 & Success of PPP-ABS $\leftarrow$ RoSD & 0.066 & 0.116 & 0.556 & 0.578 & Not supported \\
H4 & Success of PPP-ABS $\leftarrow$ MoRI & 0.006 & 0.062 & 0.079 & 0.937 Not supported \\
H5 & IC $\leftarrow$ UAQ & 0.510 & 0.136 & 4.265 & $0.003^{2}$ & Supported \\
H6 & IC $\leftarrow$ OEHC & 0.093 & 0.075 & 1.399 & 0.162 & Not supported \\
H7 & IC $\leftarrow$ ROSD & 0.218 & 0.118 & 2.291 & $0.022^{1}$ & Supported \\
H8 & IC $\leftarrow$ MORI & 0.137 & 0.062 & 2.311 & $0.021^{1}$ & Supported \\
H9 & Succes of PPP-ABS $\leftarrow$ IC & 0.243 & 0.094 & 2.05 & $0.04^{1}$ & Supported \\
H10 & OEHC $\leftarrow$ UAQ & 0.717 & 0.061 & 9.072 & $0.001^{2}$ & Supported \\
H11 & ROSD $\leftarrow$ UAQ & 0.789 & 0.061 & 8.874 & $0.002^{2}$ & Supported \\
H12 & MORI $\leftarrow$ UAQ & 0.659 & 0.064 & 8.513 & $0.001^{2}$ & Supported \\
H13 & ROSD $\leftarrow$ OEHC & 0.644 & 0.057 & 8.070 & $0.002^{2}$ & Supported \\
H14 & MORI $\leftarrow$ OEHC & 0.553 & 0.062 & 7.696 & $0.0033^{2}$ & Supported \\
H15 & MORI $\leftarrow$ ROSD & 0.585 & 0.060 & 7.559 & $0.001^{2}$ & Supported \\
\hline
\end{tabular}

1,2 Represent the correlation being significant at the 0.05 and 0.01 levels.

The UAQ is the greatest CSF with a path coefficient of 0.381 . This factor consists of the following subfactors: (1) rationality of PPP implementation plan (UAQ1), (2) stability of cash flow (UAQ2), and (3) capability of local government (UAQ3). The private sector protection clause existing in the PPP plan is important for the success of PPP-ABS. Private sector protection clauses include the minimum demand protection from the government and an exclusive clause from administrative power [7,43,44]. A government minimum demand guarantee means that if the actual use of infrastructure delivered by the PPP project is lower than the break-even point agreed on in the PPP contract, then the local government shall pay the insufficient section below the appointed minimum demand [95]. Moreover, the exclusive clause means that the local government cannot approve a new similar infrastructure project in the area of the existing PPP project. The purpose of the above clauses is to protect the private sector in the background of the Chinese strong 
government [96]. The protection of the private sector would be interpreted as a sign of the stable returns of the PPP-ABS product. It is important to boost the confidence of the PPP-ABS market investors who arrange the private sector protection clause. Many scholars believe that such clauses are important to the success of PPPs not listed in a marked position $[30,91]$. In some studies, these clauses are incorporated in the factor of strong government commitments rather than listed separately [32,33,40]. Stable cash flow of underlying assets is a strong guarantee for market investors in nearly all ABS products [65]. If the potential demand of a PPP project is deficient or fluctuant, then the solvency of the ABS product will probably face a crisis. This result is explained by the importance of a prospect in the financial market $[67,75]$. Measures of remediation still exist, even though potential demands are deficient for a certain PPP project, which includes a government guarantee. However, for an ABS product, an adverse prospect may cause disastrous consequence when the relief measures possess uncertainty.

The OEHC received a path coefficient of 0.204 . The attributes under this factor are (1) ownership attribute, (2) private sector with good reputation, (3) private sector with operating capability, (4) private sector with financial capability, and (5) private sector with capability of technical progress. In China, state-owned enterprises (SOEs) are permitted to participate in PPP projects and account for a large proportion in PPP investment [5]. SOEs are more convenient in financing than other companies, such as private enterprises and foreign companies $[97,98]$. SOEs have obvious advantages in terms of receiving financial support, which consists of conveniences in financing cost, debt guarantee and credit enhancement, compared with other companies that find it difficult to obtain support from financial institutions. The 'ownership discrimination' still exists in the Chinese financial sector, which depends on the rigid financial support of SOEs [97]. Investors of PPP projects with strong financing capacity can cope with difficulty and can bring more stable cash flow. Therefore, the ownership attribute of the original equity holder has an important impact on the success of PPP-ABS. Many studies share this view to varying degrees. A strong consortium is an integral part of the success of PPP projects [40,74]. Financing ability rising from a favorable ownership attribute plays an indispensable role in forming a strong consortium $[27,91]$. Strong financing ability naturally enhances the ability to withstand risk and to create a stable cash flow, which are particularly important for ABS products [53].

However, H3, H4 and $\mathrm{H} 6$ hypotheses are not supported by the model estimation. Hypothesis $\mathrm{H} 3$ is not supported, which may be due to the following reasons. Firstly, the key to ABS design is through the structural adjustment of credit to spread or transfer risks. Therefore, the positive effect of RoSD on the success of PPP-ABS was underestimated. Secondly, the regulatory authority required high underlying asset quality, which may lead to part of the respondents ignoring the effect of RoSD. There is a possibility that explains why H4 was not supported. Some respondents may believe that MoRI has an indirect or even negative effect on the success of PPP-ABS because of the complexity of PPP-ABS products, the difficulty of acquiring risk-related information and the uncertainty of the legality, accounting, and taxes. There is a reason why hypothesis $\mathrm{H} 6$ is not supported. The pursuit of the PPP-ABS is financing based on credit of assets instead of assets' owners, but this has not happened completely in practice. Market investors keep their eyes on the credit of original equity holders, which will affect the credit rating and issuing interest rate of the PPP-ABS products.

\subsection{Mediating Effect of Issuance Characteristics (IC)}

According to the estimation of the path coefficient above, the RoSD and MoRI cannot directly influence the success of PPP-ABS ( $p$ value is 0.578 and 0.937 , respectively) and the path coefficient of OEHC on IC is also not estimated to be significant ( $p$ value is 0.162 ). Therefore, the first two paths were considered possibly with full mediation and tested. The third path was not accounted for in this part. The standardized total, direct and indirect effect were analyzed to determine whether there is an obvious indirect effect between each variable. As shown in Table 8, the total, direct and indirect effect values of UAQ on the 
success of PPP-ABS are 0.505, 0.381 and 0.124 , respectively. Similarly, $0.227,0.204$ and 0.023 represent the total, direct and indirect effects of OEHC on the success of PPP-ABS. Thus, UAQ and OEHC have indirect effects on the success of PPP-ABS certainly [99]. Path effects after adding a mediating variable (i.e., IC) illustrated that IC mediates the relationship between the success of PPP-ABS and UAQ, RoSD and MoRI, respectively, which means that, except H17, hypotheses H16, H18 and H19 are supported.

Table 8. Results of mediating effect (Source: Authors' calculations).

\begin{tabular}{cccc}
\hline Path & Standardized Total Effect & Standardized Direct Effect & Standardized Direct Effect \\
\hline $\mathrm{UAQ} \rightarrow$ Success of PPP-ABS & 0.505 & 0.381 & 0.124 \\
$\mathrm{OEHC} \rightarrow$ Success of PPP-ABS & 0.227 & 0.204 & 0.023 \\
$\mathrm{UAQ} \rightarrow \mathrm{IC}$ & 0.510 & 0.510 & 0 \\
RoSD $\rightarrow$ IC & 0.218 & 0.218 & 0 \\
MoRI $\rightarrow$ IC & 0.137 & 0.137 & 0 \\
$\mathrm{IC} \rightarrow$ Success of PPP-ABS & 0.243 & 0.243 & 0 \\
$\mathrm{UAQ} \rightarrow \mathrm{IC} \rightarrow$ Success of PPP-ABS & 0.1239 & 0.1239 & 0 \\
$\mathrm{R}$ SD $\rightarrow$ IC $\rightarrow$ Success of PPP-ABS & 0.0530 & 0.0530 & 0 \\
$\mathrm{MoRI} \rightarrow \mathrm{IC} \rightarrow$ Success of PPP-ABS & 0.0333 & 0.0333 & 0 \\
\hline
\end{tabular}

The issuance characteristics not only have an impact on the success of PPP-ABS, but also play a mediating role between CSFs and PPP-ABS success. This finding is similar to that of previous studies. For example, Chu et al. (2017), believed that the issuing duration, issuing scale and other characteristics have a significant impact on the success of ABS products. This partly explains the positive effect of issuance characteristics on the success of PPP-ABS [22]. Furthermore, repayment characteristics are subject to the underlying asset quality and security design $[66,81]$. The results reveal the mediating effect to be more nuanced and comprehensive.

\subsection{Contribution to Existing Literature}

Based on questionnaire survey data, a theoretical model was developed using a SEM approach. Through factor analysis and path analysis, the relationship between CSFs and the success of PPP-ABS was tested. As a result, fifteen hypotheses were supported while four hypotheses were not supported. This analysis reveals the mechanism by which CSFs influence the success of PPP-ABS, which in turn is helpful in distinguishing the many factors affecting the success of PPP-ABS. Moreover, a further finding is the mediating effect on the relation between CSFs and the success of PPP-ABS. Consequently, mediating variables should not be neglected when analyzing the influence of CSFs on the success of PPP-ABS.

\subsection{Managerial Implications for Practice}

From the perspective of practice, the implications are as follows. Firstly, the theoretical model can be transferred to an assessment system for evaluating PPP-ABS projects in practice. For example, whether or not a PPP project is equipped with these success factors can be a criterium for assessing the feasibility of using ABS for financing. Secondly, regulatory authorities may formulate policy in line with the relation between CSFs and the success of PPP-ABS, and thus exert approval criteria on that basis. Finally, the findings of this study are useful for the management of enterprises engaging in PPP investment, financing and financial institutions. On the one hand, PPP investors will be aided by in-depth knowledge regarding PPP-ABS success in matters of project selection, bidding quotation and project financing. On the other hand, financial institutions will benefit from an understanding regarding PPP-ABS projects' asset quality and risk profiles. 


\section{Conclusions}

The implementation of PPP-ABS is full of challenges, and the goal of any endeavor is to be successful. There are many factors that contribute to the success of PPP-ABS. Over the last decade, research interest in PPPs has showed an increasing trend. However, a systematic analysis of CSFs in PPP-ABS has not been available up to now. Because of the availability of limited resources, it is difficult for any business owner to focus on many factors at a time. Hence, it is essential to identify those factors that are of prime importance to success. This study attempted to find a set of factors affecting the success of PPP-ABS through reviewing literatures, conducting a questionnaire survey and adopting a SEM approach. The main conclusions follow.

1. UAQ influences positively the success of PPP-ABS. This finding implies that the investors of a PPP project should carefully focus on asset quality to ensure the success of PPP-ABS issuance. Developing appropriate strategies for gathering sufficient and stable demand and appointing private sector protection clauses to enhance quality of underlying asset are the primary priorities for investors who aim to promote PPP-ABS.

2. OEHC has a positive influence on the success of PPP-ABS. The credit of the original equity holder has an important impact on the success of PPP-ABS. Corporations that have good credit will have obvious advantages in terms of receiving financial support, which consists of conveniences in financing cost, debt guarantee and credit enhancement. Strong financing ability naturally enhances the ability to withstand risk and to create a stable cash flow, which are particularly important for ABS products.

3. IC are an important mediating variable of driven factors on the success of PPP-ABS. For government, establishing and executing regulation institution and perfecting accounting and tax standards are measures that help bring policies that promote the implementation of PPP-ABS. Strict inspection is helpful to make PPP-ABS products more suitable for issuance. In addition, finding the mediating effect of IC contributes to knowledge of PPP-ABS and reminds professionals of the influence of the IC factor in practice.

4. An understanding of the direct and indirect effects and success mechanisms of PPPABS highlights which factors are crucial to establishing assessment criteria for PPPABS projects, as well as informing regulatory policies.

\section{Limitation and Future Research}

Data access is the main limitation of this study. Only a limited number of experts were approached in order to modify the CSF list. Further evidence derived from a richer dataset should be used in any follow-up research. Specifically, an empirical analysis or a case study would provide better understanding of the relationship between CSFs and the success of PPP-ABS. In further research, a quantitative approach based on open data may be applied to analyze the effects of the factors on the success of PPP-ABS.

Author Contributions: Conceptualization, L.L.; Investigation, L.L. and Y.G.; Methodology, L.L.; Supervision, Y.G. and C.C.; Writing—original draft, L.L.; Writing—review \& editing, Y.G., C.C. and I.M. All authors have read and agreed to the published version of the manuscript.

Funding: This research was funded by National Natural Science Foundation of China, grant number 71971147.

Institutional Review Board Statement: Not applicable.

Informed Consent Statement: Not applicable.

Data Availability Statement: Available on request.

Acknowledgments: The authors thank those who assisted in data collection.

Conflicts of Interest: The authors declare no conflict of interest. 


\section{References}

1. Carter, L.; Kaga, R.; Maier, T.; Heathcote, C.; Aguerre, J.A.; Abdelwahab, W.; Alter, R.; Hamilton, G.; Akhtar, S. The PPP Reference Guide; The World Bank Group: Washington, DC, USA, 2017; pp. 1-67.

2. National Development and Reform Commission. Guiding Opinion on Implementation Public-Private Partnerships. Available online: http:/ / www.ndrc.gov.cn/gzdt/201412/t20141204_651014.html (accessed on 2 December 2014). (In Chinese)

3. Ministry of Finance. Notice on Issues Related to the Promotion and Application of Public-Private Partnerships Model. Available online: http://jrs.mof.gov.cn/zhengwuxinxi/zhengcefabu/201409/t20140924_1143760.html (accessed on 23 September 2014). (In Chinese)

4. Garvin, M.J.; Bosso, D. Assessing the Effectiveness of Infrastructure Public_Private Partnership Programs and Projects. Public Work. Manag. Policy 2008, 13, 162-178. [CrossRef]

5. China Public Private Partnerships Center. Quarterly Report of National PPPs Projects Development. Available online: https: / / www.cpppc.org/jb/999691.jhtml (accessed on 29 December 2020). (In Chinese).

6. Guo, Y.; Martek, I.; Chen, C. Policy Evolution in the Chinese PPP Market: The Shifting Strategies of Governmental Support Measures. Sustainability 2019, 11, 4872. [CrossRef]

7. Armada, M.J.R.; Pereira, P.J.; Rodrigues, A. Optimal subsidies and guarantees in public-private partnerships. Eur. J. Financ. 2012, 18, 469-495. [CrossRef]

8. National Development and Reform Commission and China Securities Regulatory Commission. Notice on Promoting the Asset-Backed Securitisation in Traditional Infrastructure Projects under Public-Private Partnership (PPP). Available online: http://www.csrc.gov.cn/pub/newsite/gszqjgb/gzdtgszj/201702/t20170227_312739.html (accessed on 21 December 2016). (In Chinese)

9. Ministry of Finance, People's Bank of China and China Securities Regulatory Commission. Notice on Standardizing the Development of ABS in Public-Private Partnerships Projects. Available online: http://jrs.mof.gov.cn/zhengwuxinxi/zhengcefabu/2017 06/t20170619_2626363.html (accessed on 7 June 2017). (In Chinese)

10. Hankang, S. The Asset Securitization of PPP Projects Analysis in China; Financial Theory Practice: Zhengzhou, China, 2019; pp. 71-78. (In Chinese)

11. Zhang, W.; Xing, Y.; Ma, X. Obstacles, Risks and Countermeasures of Asset-Backed Securitisation of PPP Projects in China; China State Finance: Hong Kong, China, 2017; pp. 41-43. (In Chinese)

12. He, J. Difficulties and Prospects of PPP Project Asset-Backed Securitisation; China State Finance: Hong Kong, China, 2018 ; pp. 49-51. (In Chinese)

13. Rockart, J.F. Critical success factors. Harv. Bus. Rev. 1979, 57, 81-91.

14. Brenes, E.R.; Mena, M.; Molina, G.E. Key success factors for strategy implementation in Latin America. J. Bus. Res. 2008, 61, 590-598. [CrossRef]

15. Machado, A.V.M.; dos Santos, J.A.N.; Quindeler, N.D.S.; Alves, L.M.C. Critical Factors for the Success of Rural Water Supply Services in Brazil. Water 2019, 11, 2180. [CrossRef]

16. Clarke, A. A practical use of key success factors to improve the effectiveness of project management. Int. J. Proj. Manag. 1999, 17, 139-145. [CrossRef]

17. Osei-Kyei, R.; Chan, A.P. Review of studies on the Critical Success Factors for Public-Private Partnership (PPP) projects from 1990-2013. Int. J. Proj. Manag. 2015, 33, 1335-1346. [CrossRef]

18. Li, B.; Akintoye, A.; Edwards, P.J.; Hardcastle, C. Critical success factors for PPP/PFI projects in the UK construction industry. Constr. Manag. Econ. 2005, 23, 459-471. [CrossRef]

19. Ismail, S. Critical success factors of public private partnership (PPP) implementation in Malaysia. Asia-Pac. J. Bus. Adm. 2013, 5, 6-19. [CrossRef]

20. Barlas, S. SEC issues revised proposed rule on shelf registration of ABS. Strateg. Financ. 2011, 93, $25-26$.

21. Lu, Z.; Peña-Mora, F.; Wang, S.Q.; Liu, T.; Wu, D. Assessment Framework for Financing Public-Private Partnership Infrastructure Projects through Asset-Backed Securitization. J. Manag. Eng. 2019, 35, 04019027. [CrossRef]

22. Chu, X.; Liu, T.; Lu, Z.; Wang, S.; Wu, D. An Empirical Study on the Spread Pricing of Asset-Backed Securitisation Products in PPP Projects; Sub National Fiscal Research: Beijing, China, 2017; pp. 13-18. (In Chinese)

23. Jingling, W.; Jiaojiao, P.; Wei, Z. A Study on Government Debt Risk of PPP Asset Securitization; Securities Market Herald: Shenzhen, China, 2017; pp. 4-11. (In Chinese)

24. Xia, S. The Research on Risk Prevention of PPP Asset Securitization in the New Stage; Hainan Finance: Hainan, China, 2018; pp. 4-9. (In Chinese)

25. Han, K. Research on Risk Management and Control of Asset Securitization in PPP Projects. Theory Pract. Financ. Econ. 2017, 38, 59-63. (In Chinese)

26. Shen, Z. Analysis of the Main Characteristics of PPP Asset-Backed Securitization; Finance Economy: Changsha, China, 2017; pp. 163-164. (In Chinese)

27. Tang, L.; Shen, Q.; Skitmore, M.; Cheng, E.W.L. Ranked Critical Factors in PPP Briefings. J. Manag. Eng. 2013, 29 , 164-171. [CrossRef]

28. Deng, Z. Risk and Policy Suggestions of PPP Project Asset-Backed Securitization from the Perspective of Audit; Wuhan Finance: Wuhan, China, 2017; pp. 55-58. (In Chinese) 
29. Ozdoganm, I.D.; Birgonul, M.T. A decision support framework for project sponsors in the planning stage of build-operate-transfer (BOT) projects. Constr. Manag. Econ. 2000, 18, 343-353. [CrossRef]

30. Osei-Kyei, R.; Chan, A.P. Implementing public-private partnership (PPP) policy for public construction projects in Ghana: Critical success factors and policy implications. Int. J. Constr. Manag. 2016, 17, 113-123. [CrossRef]

31. Hwang, B.-G.; Zhao, X.; Gay, M.J.S. Public private partnership projects in Singapore: Factors, critical risks and preferred risk allocation from the perspective of contractors. Int. J. Proj. Manag. 2013, 31, 424-433. [CrossRef]

32. Cheung, E.; Chan, A.P.; Kajewski, S.L. Factors contributing to successful public private partnership projects. J. Facil. Manag. 2012, 10, 45-58. [CrossRef]

33. Lam, P.T.I.; Chiang, Y.H.; Chan, S.H. Critical Success Factors for Bond Financing of Construction Projects in Asia. J. Manag. Eng. 2011, 27, 190-199. [CrossRef]

34. Hanson, S.G.; Sunderam, A. Are there too many safe securities? Securitization and the incentives for information production. J. Financ. Econ. 2013, 108, 565-584. [CrossRef]

35. Meng, X.; Zhao, Q.; Shen, Q. Critical Success Factors for Transfer-Operate-Transfer Urban Water Supply Projects in China. J. Manag. Eng. 2011, 27, 243-251. [CrossRef]

36. Zhang, X. Critical Success Factors for Public-Private Partnerships in Infrastructure Development. J. Constr. Eng. Manag. 2005, 131, 3-14. [CrossRef]

37. Riddiough, T.J. Optimal Design and Governance of Asset-Backed Securities. J. Financ. Intermediation 1997, 6, 121-152. [CrossRef]

38. Hou, Y. Analysis and Evaluation of Operational Risk Based on the Whole Process of PPP Asset Securitization; Finance and Accounting Monthly: Wuhan, China, 2018; p. 12. (In Chinese)

39. Yu, Y.; Chan, A.P.C.; Chen, C.; Darko, A. Critical Risk Factors of Transnational Public-Private Partnership Projects: Literature Review. J. Infrastruct. Syst. 2018, 24, 04017042. [CrossRef]

40. Chan, A.P.C.; Lam, P.T.I.; Chan, D.W.M.; Cheung, E.; Ke, Y. Critical Success Factors for PPPs in Infrastructure Developments: Chinese Perspective. J. Constr. Eng. Manag. 2010, 136, 484-494. [CrossRef]

41. Feng, Y.; Li, N.; Zuo, S. Study on Key Factors of the Success of PPP Models; Public Finance Research: Shandong, China, 2017; pp. 51-58. (In Chinese)

42. Feng, K.; Xiong, W.; Wang, S.; Wu, C.; Xue, Y. Optimizing an Equity Capital Structure Model for Public-Private Partnership Projects Involved with Public Funds. J. Constr. Eng. Manag. 2017, 143, 04017067. [CrossRef]

43. Wibowo, A.; Kochendoerfer, B. Selecting BOT/PPP Infrastructure Projects for Government Guarantee Portfolio under Conditions of Budget and Risk in the Indonesian Context. J. Constr. Eng. Manag. 2011, 137, 512-522. [CrossRef]

44. Wang, L.; Shrestha, A.; Zhang, W.; Wang, G. Government Guarantee Decisions in PPP Wastewater Treatment Expansion Projects. Water 2020, 12, 3352. [CrossRef]

45. Buscaino, V.; Caselli, S.; Corielli, F.; Gatti, S. Project Finance Collateralised Debt Obligations: An Empirical Analysis of Spread Determinants. Eur. Financ. Manag. 2010, 18, 950-969. [CrossRef]

46. Xu, Y.; Sun, C.; Skibniewski, M.J.; Chan, A.P.; Yeung, J.F.; Cheng, H. System Dynamics (SD)-based concession pricing model for PPP highway projects. Int. J. Proj. Manag. 2012, 30, 240-251. [CrossRef]

47. Zhang, X.; Bao, H.; Wang, H.; Skitmore, M. A model for determining the optimal project life span and concession period of BOT projects. Int. J. Proj. Manag. 2016, 34, 523-532. [CrossRef]

48. Lv, J.; Ye, G.; Liu, W.; Shen, L.; Wang, H. Alternative Model for Determining the Optimal Concession Period in Managing BOT Transportation Projects. J. Manag. Eng. 2015, 31, 04014066. [CrossRef]

49. Liang, Y.; Wang, H. Sustainable Performance Measurements for Public-Private Partnership Projects: Empirical Evidence from China. Sustainability 2019, 11, 3653. [CrossRef]

50. De Albornoz, V.A.C.; Galera, A.L.; Millán, J.M. Is It Correct to Use the Internal Rate of Return to Evaluate the Sustainability of Investment Decisions in Public Private Partnership Projects? Sustainability 2018, 10, 4371. [CrossRef]

51. Dulaimi, M.F.; Alhashemi, M.; Ling, F.Y.Y.; Kumaraswamy, M. The execution of public-private partnership projects in the UAE. Constr. Manag. Econ. 2010, 28, 393-402. [CrossRef]

52. Jeong, J.; Ji, C.; Hong, T.; Park, H.S. Model for Evaluating the Financial Viability of the BOT Project for Highway Service Areas in South Korea. J. Manag. Eng. 2016, 32, 04015036. [CrossRef]

53. China Securities Regulatory Commission. Guidelines for the Confirmation of Listing Conditions for Infrastructure Asset-Backed Securities. Available online: http://www.csrc.gov.cn/pub/newsite/gszqjgb/zcfggszq/zlgzzcfg/201806/t20180615_339949.html (accessed on 25 December 2020). (In Chinese)

54. Yan, X.; Chong, H.-Y.; Sheng, Z.; Wang, X. Financing Decision Model for Toll Roads: Balancing Eco-nomic and Public Attributes. J. Manag. Eng. 2017, 33, 04017010. [CrossRef]

55. Wang, N. Correlation Analysis of Capital and Life Cycle Costs in Private Financial Initiative Projects. J. Manag. Eng. 2014, 30, 06014002. [CrossRef]

56. Wu, Y.; Chen, Z.; Chen, J. The Credibility of Local Government and the Scale of PPP Project: Based on the Data of the PPP Project: Based on the Data of the PPP Project Database of the Ministry of Finance. Mod. Financ. Econ. J. Tianjin Univ. Financ. Econ. 2019, 1, 3-13. (In Chinese)

57. Yang, Y.; Hou, Y.; Wang, Y. On the Development of Public-Private Partnerships in Transitional Economies: An Explanatory Framework. Public Adm. Rev. 2013, 73, 301-310. [CrossRef] 
58. Allen, F.; Qian, J.; Qian, M. Law, finance, and economic growth in China. J. Financ. Econ. 2005, 77, 57-116. [CrossRef]

59. Zou, C. Credit rating inflation and the ownership discrimination on financing-Based on Chinese corporate bond data. Res. Econ. Manag. 2015, 36, 44-52. (In Chinese)

60. Wang, H.; Ma, L. Ownership, corruption, and revenue regimes for infrastructure partnerships: Evidence from China. Util. Policy 2019, 60, 100942. [CrossRef]

61. Li, H.; Lv, L.; Zuo, J.; Su, L.; Wang, L.; Yuan, C. Dynamic Reputation Incentive Mechanism for Urban Water Environment Treatment PPP Projects. J. Constr. Eng. Manag. 2020, 146, 04020088. [CrossRef]

62. Cao, Q.; Zhou, J.; Zhaohan, S. Study on Dynamic Incentive Mechanism of Public Private Partnerships Based on the Reputation Theory. Soft Sci. 2016, 30, 20-23. (In Chinese)

63. Schaufelberger, J.E.; Wipadapisut, I. Alternate Financing Strategies for Build-Operate-Transfer Projects. J. Constr. Eng. Manag. 2003, 129, 205-213. [CrossRef]

64. Liu, B.; Abe, M.; Xie, F.; Subhanij, T. Asset-Backed Securitization of PPP Projects: The Case of China. Chin. Econ. 2020, 53, 1-13. [CrossRef]

65. Li, H.; Jin, H.; Wang, D. Research on the Asset-Backed Securitization Financing of Large Stadium. Int. Bus. Res. 2011, 4, 90. [CrossRef]

66. Zhang, Y.; Yang, Z.; Luo, P. The Model Choice and Design of Credit Assets Securitisation. Chin. J. Manag. Sci. 2017, 24, 1-9. (In Chinese)

67. De Albornoz, V.A.C.; Soliño, A.S. Is there room for a PPP secondary market? Financial analysis of the PPP transport sector. J. Manag. Eng. 2015, 31, 04014084. [CrossRef]

68. Joshi, J. Solar Securitization: Understanding the Risks of Residential Solar Energy-Backed Securities from an Investor Perspective. J. Struct. Financ. 2013, 19, 64-70. [CrossRef]

69. Li, Y.; Yu, J. External Effects of the Redemption Mechanism of Open-end Funds. J. Financ. Econ. 2004, 30, 111-120. (In Chinese)

70. He, J. When PPP Meets Asset Securitization-The First PPP Experience Enlightenment Project of As-set-Backed Special Programs. Open J. Soc. Sci. 2019, 7, 120-131. [CrossRef]

71. Li, S.; Abraham, D.; Cai, H. Infrastructure financing with project bond and credit default swap under public-private partnerships. Int. J. Proj. Manag. 2017, 35, 406-419. [CrossRef]

72. Feng, S. Analysis of the Credit Rating System on Securitization and Related Systemic Risk. Theory Pract. Financ. Econ. 2017, 38, 139-144. (In Chinese)

73. Yu, D. Application of Asset Securitization in PPP Project; Communication of Finance and Accounting: Wuhan, China, 2018; pp. 17-20. (In Chinese)

74. Jefferies, M. Critical success factors of public private sector partnerships. Eng. Constr. Arch. Manag. 2006, 13, 451-462. [CrossRef]

75. Plowe, J.; McMahon, D.; Phillips, J.; Rosen, G. Alternative Capital Markets Solutions in Renewable Energy Finance. J. Struct. Financ. 2014, 20, 46-48. [CrossRef]

76. Fu, Q.; Xiang, X. Research on Tax Policy for PPP Mode; Finance and Accounting Monthly: Wuhan, China, 2018; pp. 48-55. (In Chinese)

77. Ashuri, B.; Mostaan, K. State of Private Financing in Development of Highway Projects in the United States. J. Manag. Eng. 2015, 31, 04015002. [CrossRef]

78. Bakri, M.H.; Sufian, F.; Hamid, B.A.; Ismail, S. Determinant of Securitization Spread in Malaysia. Int. J. Bus. Soc. 2018, 19, 904-917.

79. Yu, D.; Papajohn, C.; Michael, T. Aircraft Lease Asset-Backed Securities and Aircraft Enhanced Equipment Trust Certificates Workouts. J. Struct. Financ. 2021, 26, 86-96. [CrossRef]

80. Rhee, J. The United Kingdom's Asset-backed Securities Guarantee Scheme (UK GFC). J. Financ. Cris. 2020, 2, 948-963.

81. Halim, Z.A.; How, J.; Verhoeven, P.; Hassan, M.K. Asymmetric information and securitization design in Islamic capital markets. Pac. Basin Financ. J. 2020, 62, 101189. [CrossRef]

82. Tang, Y.; Chen, D.; Chen, J.; Xu, J. The rise of China's securitization market. Financ. Mark. Inst. Instrum. 2017, 26, 279-294. [CrossRef]

83. Mok, K.Y.; Shen, G.Q.; Yang, J. Stakeholder management studies in mega construction projects: A review and future directions. Int. J. Proj. Manag. 2015, 33, 446-457. [CrossRef]

84. Turner, J.R. Handbook of Project-Based Management: Leading Strategic Change in Organizations; McGraw-Hill Education: Boston, MA, USA, 2009; pp. 3-87.

85. Belassi, W.; Tukel, O.I. A new framework for determining critical success/failure factors in projects. Int. J. Proj. Manag. 1996, 14, 141-151. [CrossRef]

86. Lim, C.; Mohamed, M. Criteria of project success: An exploratory re-examination. Int. J. Proj. Manag. 1999, 17, 243-248. [CrossRef]

87. Tripathi, K.K.; Jha, K.N. Determining Success Factors for a Construction Organization: A Structural Equation Modeling Approach. J. Manag. Eng. 2018, 34, 04017050. [CrossRef]

88. China Securities Regulatory Commission. Provisions on the Management of Asset Securitization Business of Subsidiaries of Securities Companies and Fund Management Companies. Available online: http://www.csrc.gov.cn/pub/newsite/flb/flfg/ bmgf/jj/gszl/201510/t20151012_284996.html (accessed on 2 December 2020). (In Chinese)

89. Zhang, S.; Chan, A.P.; Feng, Y.; Duan, H.; Ke, Y. Critical review on PPP Research-A search from the Chinese and International Journals. Int. J. Proj. Manag. 2016, 34, 597-612. [CrossRef] 
90. Hu, Z.; Li, Q.; Liu, T.; Wang, L.; Cheng, Z. Government equity investment, effective communication and public private partnership (PPP) performance: Evidence from China. Eng. Constr. Arch. Manag. 2020. ahead-of-print. [CrossRef]

91. Ng, S.T.; Wong, Y.M.; Wong, J.M. Factors influencing the success of PPP at feasibility stage-A tripartite comparison study in Hong Kong. Habitat Int. 2012, 36, 423-432. [CrossRef]

92. Hair, J.F. Multivariate Data Analysis, 7th ed.; Pearson Prentice Hall: Upper Saddle River, NJ, USA, 2009 ; pp. 25-162.

93. Ong, T.F.; Musa, G. Examining the influences of experience, personality and attitude on SCUBA divers' underwater behaviour: A structural equation model. Tour. Manag. 2012, 33, 1521-1534. [CrossRef]

94. Chen, Y.Q.; Zhang, Y.B.; Liu, J.Y.; Mo, P. Interrelationships among Critical Success Factors of Construction Projects Based on the Structural Equation Model. J. Manag. Eng. 2012, 28, 243-251. [CrossRef]

95. Ashuri, B.; Kashani, H.; Molenaar, K.; Lee, S.; Lu, J. Risk-neutral pricing approach for evaluating BOT highway projects with government minimum revenue guarantee options. J. Constr. Eng. Manag. 2012, 138, 545-557. [CrossRef]

96. Kwofie, T.E.; Afram, S.; Botchway, E. A critical success model for PPP public housing delivery in Ghana. Built Environ. Proj. Asset Manag. 2016, 6, 58-73. [CrossRef]

97. Zhang, J. Financial Difficulties and Financing Sequences of Private Economy. Econ. Res. J. 2000, 4, 10. (In Chinese)

98. Zhang, S.; Gao, Y.; Feng, Z.; Sun, W. PPP application in infrastructure development in China: Institutional analysis and implications. Int. J. Proj. Manag. 2015, 33, 497-509. [CrossRef]

99. Preacher, K.J.; Hayes, A.F. Asymptotic and resampling strategies for assessing and comparing indirect effects in multiple mediator models. Behav. Res. Methods 2008, 40, 879-891. [CrossRef] [PubMed] 